\title{
鋼構造溶接接合部の高温引張実験 \\ TENSILE TESTS OF STEEL WELDED JOINTS AT HIGH TEMPERATURE
}

\author{
川崎有貴*, 尾崎文宣** \\ Yuki KAWASAKI and Fuminobu OZAKI
}

\begin{abstract}
In this paper, both load bearing and deformation performance for welded joints at high temperature are investigated by tensile member tests under a condition on constant temperature and load increase. Specimens including a full penetration weld (FW) and a partial penetration weld (PW) are used for the tests, respectively. From specimen observations after the tests, it was observed that the PW specimens fractured at weld metal in the partial penetration joint and the FW specimen over $800{ }^{\circ} \mathrm{C}$ fractured along fusion lines between the base metal and the full penetration joint. On the other hand, the FW specimens under $800{ }^{\circ} \mathrm{C}$ fractured at the base metal. It was confirmed that the specimens fractured at the welted joints possessed the sufficient load bearing and deformation capacity at the high temperature and both welded joint and base metal exhibited the similar reduction factors on steel strength at high temperature.
\end{abstract}

Keywords : welded joint, fire resistance, full penetration weld, partial penetration weld, tensile test at high temperature 溶接接合部，而火性能，完全溶け込み溶接，部分溶け込み溶接，高温引張実験

\section{1. はじめに}

兵庫県南部地震では、鋼構造柱梁接合部の脆性破壞事例が多数報 告され、その後、各種溶接接合部の耐震性に関する研究・技術開発 が数多く実施されてきた。溶接接合部の脆性的破断を回避するため のディテールや設計指針およびガイドラインなどが提案され 1,2)、 これらにより溶接接合部の耐震性向上が図られるに至っている。一 方で、鋼構造の溶接接合部の耐火性能に関する研究は少なく、鋼構 造耐火設計指針 ${ }^{3)}$ (以下、AIJ 指針) においてその研究の必要性が述 ベられているが、殆ど研究が進んでいないのが実状である。このこ とは、高力ボルト接合部の耐火研究は比較的数多く実施されており 4 6)、AIJ 指針においてもそれらの耐火性能評価法が提案されている のとは対照的である。火災時における溶接接合部の問題としては、 脆性的な破壊に関するものと、温度上昇に伴う溶接金属や熱影響部 の耐力低下に関するものが考えられる ${ }^{7)}$ 。前者に関しては、文献 ${ }^{8)}$ において柱梁溶接接合部の熱影響部が $400{ }^{\circ} \mathrm{C}$ の温度域において脆 性破壊した実験結果が報告されており、火災時においても脆性破壊 の問題が存在することが示されている。一方で、 $400{ }^{\circ} \mathrm{C}$ 以上の温度 域においては、鋼材の青熱脆化域を超えることから脆性破壊の問題 は影を潜め、この場合は後者の問題、すなわち溶接接合部の高温耐 力の問題が支配的になると考えられる ${ }^{7)}$ 。梁端部の溶接接合部近傍
には高温塑性ヒンジが形成される可能性があり、したがって高温耐 力の他に変形能力も要求されることとなる ${ }^{9)}$ 。特に梁端部の下フラ ンジ部には、梁の断面せい方向の温度勾配により引張側の熱応力が 発生することが指摘されており ${ }^{10)}$ 、当該熱応力を減衰するためにも 溶接接合部の高温耐力〜変形性能を明らかにしておく必要があると 考えられる。溶接接合部の高温耐力に関する既往研究としては、文 献 ${ }^{11)}$ において高温素材試験結果が報告されている。完全溶け込み溶 接接合部から素材引張試験片を切り出して高温素材試験を実施して おり、これによると母材が SN490B で溶接材料が YGW-11 の組合せで は $700{ }^{\circ} \mathrm{C}$ 以上の温度域で試験片内の溶接金属部で高温破断するこ と、またこの場合の高温時耐力と伸びは母材部で高温破断した他の 試験片と同等であったことが報告されている。上記試験結果は溶接 接合部の耐火性能評価に対して貴重なデータを与えるものであるが、 小型素材試験片の実験結果であるので、実際の溶接接合部のディテ ールを持つ部材レベルの耐火性能は不明のままである。

本研究の主目的は、完全および部分溶け込み溶接接合部を設けた 鋼板試験体に対して温度一定・荷重漸増の高温引張試験を行い、そ れらの高温耐力と変形性能の実験データを取得・蓄積することにあ る。溶接接合部の高温破断モードを調查し、また得られた実験デー タから溶接接合部の高温強度残存率と変形性能を検討する。なお、
$*$ 名古屋大学大学院環境学研究科 大学院生 ·学士 (工学)

** 名古屋大学大学院環境学研究科 准教授・博士 (工学)
Grad. Stud., Grad. S. Environmental Studies, Nagoya Univ., B.Eng. Assoc. Prof., Grad. S. Environmental Studies, Nagoya Univ., Dr.Eng. 
溶接接合部の火災後再利用を検討するための実験データ取得のため に、 1 温度水準ではあるが加熱冷却後の溶接接合部の引張実験も実 施しており、その結果についても報告する。

\section{2. 実験概要}

\section{1 試験体概要および実験条件}

図 1〜3に、溶接接合部を設けた鋼板試験体の詳細を示す。試験 体中央部に完全および部分溶け込久溶接接合部を設けた FW と PW 試 験体(図 1、2)、および溶接接合部を有しない鋼板試験体 (以下、P 試験体 (図 3 参照)）を用意した。鋼構造骨組内の梁材端部における 応力勾配を模擬するために、文献 ${ }^{12)}$ にるる溶接部試験体を参考に して、試験体を直線のテーパー形状に加工し、これにより試験体中 央が最大応力断面になるように製作した。この試験体テーパー部の 具体的な寸法に関しては、後述の電気加熱炉の内径や加熱区間長、 炉内における変位治具とのとり合い等も考慮して決定した。試験体 内のテーパー区間の長さを L とし、引張実験では当該区長 $\mathrm{L}$ の材軸 方向相対変位を測定した。試験体板厚は、P と PW 試験体は全区間 $12 \mathrm{~mm}$ 、一方 $\mathrm{FW}$ 試験体では、図 1 に示寸試験体中央の溶接接合部よ り右側の鋼板 (テーパー区間を含む鋼板) は $12 \mathrm{~mm}$ 、一方、左側は 16 $\mathrm{mm}$ の板厚を用いた。板厚が大きな $16 \mathrm{~mm}$ の鋼板を用いたのは、最 小断面位置となる試験体中央の完全溶け込み溶接部が、最大応力箇 所になるようにするためである。また、完全溶け込み溶接が多用さ れる通しダイアフラム形式の柱梁溶接接合部においては、ダイアフ ラムは梁 $\mathrm{H}$ 形断面のフランジより一般に板厚が大きくなるので、そ れを踏まえてダイアフラム部を想定した試験体左側鋼板の板厚を大 きくした。試験体の鋼種は、母材は SN490B、溶接材料は YGW-11 と し、それらの検查証明書情報および化学成分は表 $1 、 2$ に示す。

図 1〜3 に示寸試験体の左右端を載荷装置に連結して引張力を載 荷するが、このとき試験体加熱部(電気炉加熱区間 $500 \mathrm{~mm}$ ) から載 荷装置への過度な熱流入を防ぐために、試験体両端部にはカバープ レート (SS400 鋼板で板厚 $12 \mathrm{~mm}$ 、図 1〜3 参照)を取り付け、これよ り載荷装置との連結部の試験体熱容量を大きくした。カバープレー トは試験体の表裏両面に取り付けた(図 6 参照)。

溶接接合部の詳細は以下の通りである。FW 試験体の溶接接合部 は半自動アーク溶接を用いた。開先形状は JASS $6^{13)}$ を基に一般的 な形状のものを用い(図 4)、パス間温度を管理した上で溶接施工し た。溶接接合部の積層数は 3 とした。なお FW 試験体では、完全溶 け込み溶接部の余盛部はそのままとした。余盛削除のためには溶接 施工後にグラインダー処理等が必要となるが、余盛処理時に板厚 $16 \mathrm{~mm}$ の鋼板をアンダーカットする恐れがあったために、余盛部は そのままにした。ただし、この余盛高さは極力低くなるように溶接 施工した。また、FW 試験体の母材に仮止めされた裏当て金(図 4 参 照)を介した荷重伝達を無くすために、裏当て金の仮止めビードは グラインダー削除した。このとき裏当て金にアンダーカットが入っ たものもあったが、これ自体は溶接接合部の性能には特に影響を与 えるものでは無い。PW 試験体は図 4 に示す $\mathrm{K}$ 型開先を用い、溶接 部の溶込断面積は母材断面積の $2 / 3$ とした。PW 試験体も FW 試験体 と同様の溶接施工を行い、溶接部積層数は表裏各 1 となった。本実 験に用いた K 型開先はルート面高さが $4 \mathrm{~mm}$ とやや小さいために、 溶接時にルート面が溶け落ちて部分溶け込み溶接では無くなる可能
性が考えられたが、後述の PW 試験体の実験後観察から K 型開先の ルート部には溶け込みが殆ど無く、全 PW 試験体は部分溶け込み溶 接になっていたことを確認した(図 14 参照)。なお PW 試験体は板厚 $12 \mathrm{~mm}$ の鋼板に統一したため(図 2、4)、溶接金属の余盛部を削除し て平面を出すことが容易であったので、溶接後にグラインダー処理 を施して余盛削除した。FW、PWの全試験体については超音波探傷 試験を実施し、溶接接合部に欠陥がないことを確認した。

表 3 に高温引張実験の温度水準を示す。FW、PW、P 試験体では、 共通の実験温度として、RT、600、700、800 ${ }^{\circ} \mathrm{C}$ を設定した。これら に加えて、FW と P 試験体は $400{ }^{\circ} \mathrm{C}$ の高温実験と、700 ${ }^{\circ} \mathrm{C}$ 加熱し た後に炉内冷却し、その後常温下で引張載荷を行う $700{ }^{\circ} \mathrm{C}$ 加熱冷 却後実験も実施した。さらに FW 試験体に関しては、800 ${ }^{\circ} \mathrm{C}$ の高温 実験において、後述のように溶接接合部が特徴的な高温破断を呈し

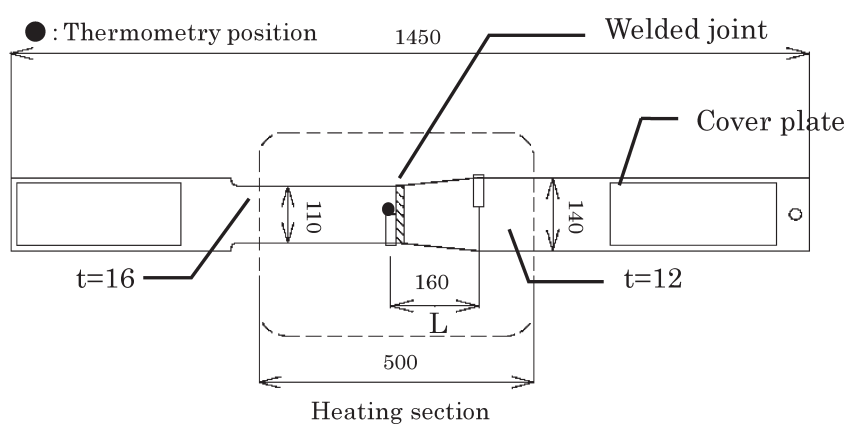

Fig.1 FW specimen

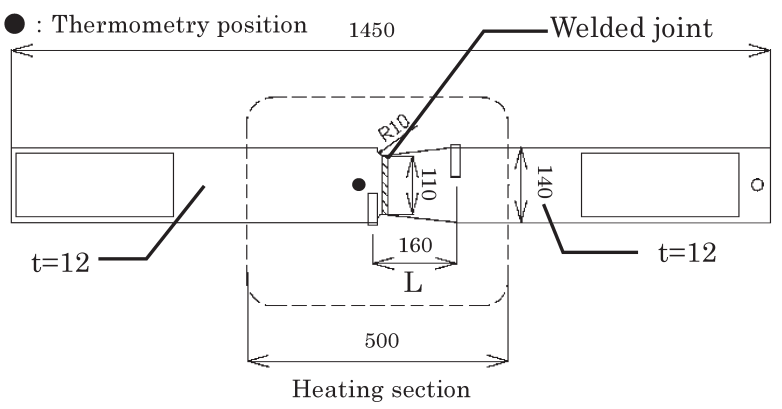

Fig.2 PW specimen

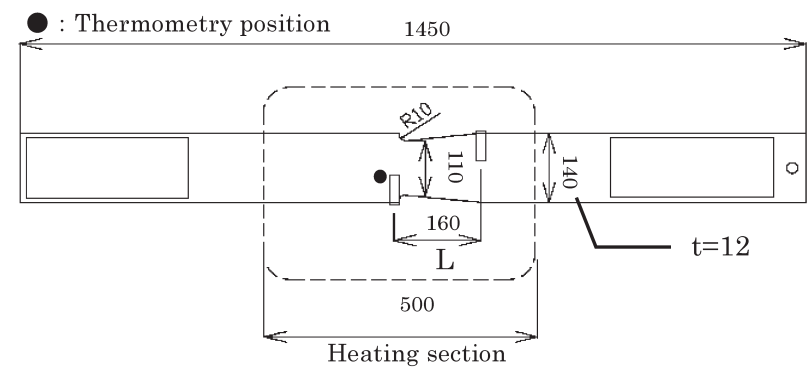

Fig.3 P specimen

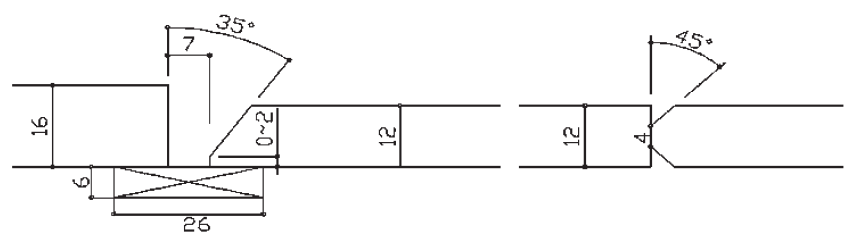

Fig.4 Welded joint details

(Left: full penetration weld, right: partial penetration weld) 
たため、750、850、900 ${ }^{\circ} \mathrm{C} の$ 高温実験を追加して実施した。各温度 における試験体数はそれぞれ 1 とし、合計 19 試験体に対して引張 実験を実施した。

\section{2 加熱方法および温度測定方法}

加熱には円筒型電気炉 (内径 $250 \mathrm{~mm}$ 、高さ $500 \mathrm{~mm}$ ) を用いた。図 5 に、載荷装置と電気炉内部にセットされた試験体の写真を示す。電 気炉加熱区間の中心に試験体中央部が位置するようにセットした。 試験体の鋼材温度はシース型 $\mathrm{K}$ 熱電対で測定した。熱電対位置は図 $1 \sim 3$ 中の印である。熱電対先端をステンレス簿で覆い、ステン レス箔を試験体にスポット溶接することで熱電対を試験体に取り付 けた。試験体を載荷装置に設置した後に電気炉内部を昇温させた。 加熱昇温速度は全試験体で $4.2 \sim 12.1{ }^{\circ} \mathrm{C} / \mathrm{min}$ であった。鋼材温度 が実験目標温度に到達後、30 分間当該温度を保持して載荷を開始 した。温度保持後の電気炉内部では、炉上部と下部で最大で約 $25{ }^{\circ} \mathrm{C}$ 温度差が生じていたが、試験体中央部に設置した熱電対の 鋼材温度は目標温度をほぼ保持することができていた。なお、上述 の加熱泠却試験 $\left(700{ }^{\circ} \mathrm{C}\right)$ に関しては、試験体の熱電対温度を $700{ }^{\circ} \mathrm{C}$ で 30 分間保持し、その後炉内泠却して常温下で載荷を行っ た。炉内冷却中の試験体温度は、30、60、120 分後にそれぞれ約 500、350、200 ${ }^{\circ} \mathrm{C}$ と低下寸ることとなった。

\section{3 載荷方法および変位測定方法}

載荷には $2000 \mathrm{kN}$ 万能引張試験機を用い、クロスヘッドを変位制 御することで荷重載荷した。変位測定区間は図 1～3 に示す L (=160 $\mathrm{mm})$ であり、変位測定区間の両端に変位取付治具 (M12 高ナット)を 設置した。電気加熱炉内では変位計を設置できないため、変位計測 用治具を試験体にセットし、それを電気炉外部に引き出して変位計 4 つを設置した(図 6 参照)。変位計(1)と (2)、および(3)と(4)の平均を 算出し、それらの相対差を求めることで変位測定区間の変形量を得 た。表 4、5には、 $600{ }^{\circ} \mathrm{C}$ 以上の高温実験の載荷開始から終了まで の試験体測定変形に対する平均載荷速度を示寸。このうち載荷開始 から最大荷重到達時までの平均載荷速度は、表 4、5 中の[]で示し た。また図 7 には、FW 試験体の高温実験時の載荷速度例 (30 秒毎の 測定値から算出)を示す。これらは文献 ${ }^{5)}$ を参考にして作図した。

Table 1 Inspection certificate of SN490B

\begin{tabular}{|c|c|c|c|c|c|}
\hline Thickness & \multicolumn{2}{|c|}{$\begin{array}{c}\text { Yield strength } \\
{\left[\mathrm{N} / \mathrm{mm}^{2}\right]}\end{array}$} & \multicolumn{2}{|c|}{$\begin{array}{c}\text { Tensile strength } \\
{\left[\mathrm{N} / \mathrm{mm}^{2}\right]}\end{array}$} & $\begin{array}{c}\text { Elongation } \\
{[\%]}\end{array}$ \\
\hline $12 \mathrm{~mm}$ & \multicolumn{2}{|c|}{364} & \multicolumn{2}{|c|}{514} & 28 \\
\hline $16 \mathrm{~mm}$ & \multicolumn{2}{|c|}{391} & \multicolumn{2}{|c|}{532} & 27 \\
\hline \multicolumn{6}{|c|}{ Chemical component (\%) } \\
\hline \multirow{2}{*}{ Thickness } & $\mathrm{C}$ & $\mathrm{Si}$ & $\mathrm{Mn}$ & $\mathrm{P}$ & $\mathrm{S}$ \\
\hline & \multicolumn{3}{|c|}{$\mathrm{x} 100$} & \multicolumn{2}{|c|}{$\mathrm{x} 1000$} \\
\hline $12 \mathrm{~mm}$ & 15 & 40 & 138 & 14 & 4 \\
\hline $16 \mathrm{~mm}$ & 15 & 39 & 138 & 15 & 4 \\
\hline
\end{tabular}

Table 2 Inspection certificate of YGW-11

\begin{tabular}{c|c|c|c|c|c|c}
\hline \multicolumn{7}{c}{ Chemical component (\%) } \\
\hline \hline $\mathrm{C}$ & $\mathrm{Si}$ & $\mathrm{Mn}$ & $\mathrm{P}$ & $\mathrm{S}$ & $\mathrm{Cu}$ & $\mathrm{Ti}+\mathrm{Zr}$ \\
\hline 0.06 & 0.77 & 1.56 & 0.01 & 0.012 & 0.25 & 0.23 \\
\hline
\end{tabular}

Table 3 Test temperature conditions

\begin{tabular}{|c|c|c|c|}
\hline Temperature & FW specimen & PW specimen & $\begin{array}{c}\text { P } \\
\text { specimen }\end{array}$ \\
\hline \hline RT & $\bigcirc$ & $\bigcirc$ & $\bigcirc$ \\
\hline $400^{\circ} \mathrm{C}$ & $\bigcirc$ & - & $\bigcirc$ \\
\hline $600^{\circ} \mathrm{C}$ & $\bigcirc$ & $\bigcirc$ & $\bigcirc$ \\
\hline $700^{\circ} \mathrm{C}$ & $\bigcirc$ & $\bigcirc$ & $\bigcirc$ \\
\hline $750^{\circ} \mathrm{C}$ & $\bigcirc$ & - & - \\
\hline $800^{\circ} \mathrm{C}$ & $\bigcirc$ & $\bigcirc$ & $\bigcirc$ \\
\hline $850^{\circ} \mathrm{C}$ & $\bigcirc$ & - & - \\
\hline $900^{\circ} \mathrm{C}$ & $\bigcirc$ & - & - \\
\hline $\begin{array}{c}\text { RT after } \\
700^{\circ} \mathrm{C} \\
\text { heating }\end{array}$ & $\bigcirc$ & - & $\bigcirc$ \\
\hline
\end{tabular}

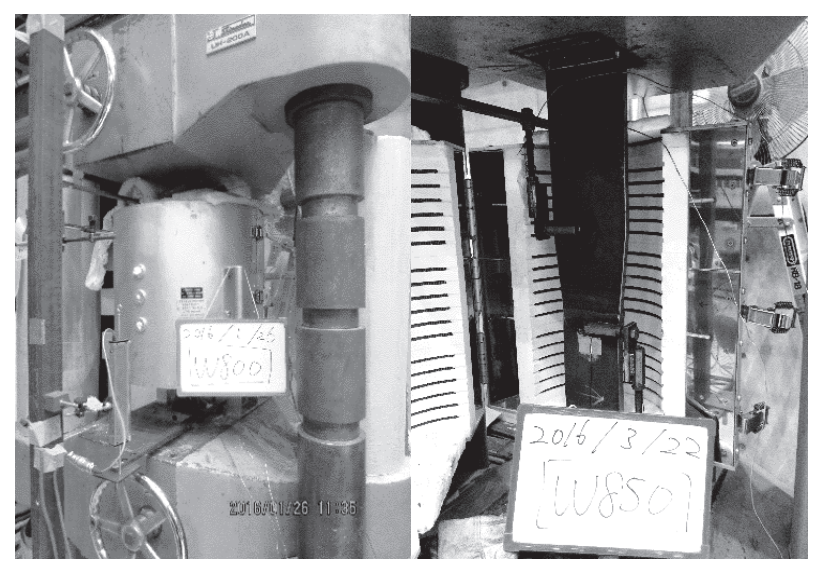

Fig.5 Photographs of overview of experimental device (Left : the outside, right : the inside)

: Displacement meters

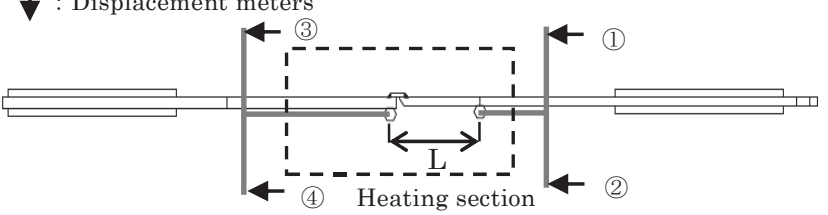

Fig.6 Displacement measurement

Table 4 Average loading speed Average loading speed $(\mathrm{mm} / \mathrm{min})$ [Average loading speed up to maximum load]

\begin{tabular}{c|r|r|r}
\hline Temperature & \multicolumn{1}{|c|}{ FW } & PW & \multicolumn{1}{c}{ P } \\
\hline \multirow{2}{*}{$600^{\circ} \mathrm{C}$} & $\begin{array}{r}1.05 \\
{[0.43]}\end{array}$ & $\begin{array}{r}0.44 \\
{[0.21]}\end{array}$ & $\begin{array}{r}1.34 \\
{[0.53]}\end{array}$ \\
& 0.75 & 0.77 & 1.14 \\
\multirow{2}{*}{$700^{\circ} \mathrm{C}$} & {$[0.24]$} & {$[0.33]$} & {$[0.49]$} \\
\hline \multirow{2}{*}{$800^{\circ} \mathrm{C}$} & 0.45 & 0.39 & 0.61 \\
& {$[0.32]$} & {$[0.33]$} & {$[0.28]$} \\
\hline
\end{tabular}

Table 5 Average loading speed[FW]

Average loading speed ( $\mathrm{mm} / \mathrm{min})$

[Average loading speed up to maximum load]

\begin{tabular}{c|c|c}
\hline $750^{\circ} \mathrm{C}$ & $850^{\circ} \mathrm{C}$ & $900^{\circ} \mathrm{C}$ \\
\hline 0.68 & 0.73 & 0.72 \\
{$[0.38]$} & {$[0.47]$} & {$[0.44]$} \\
\hline
\end{tabular}




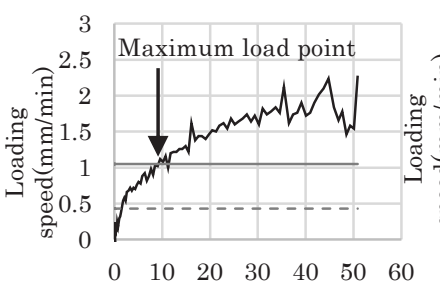

Specimen deformation $(\mathrm{mm})$

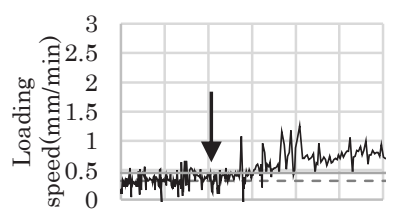

$\begin{array}{lllllll}0 & 10 & 20 & 30 & 40 & 50 & 60\end{array}$

Specimen deformation $(\mathrm{mm})$

Fig.7 Example of loading speed(Upper left : FW[600 $\left.{ }^{\circ} \mathrm{C}\right]$, upper right : $\mathrm{FW}\left[700{ }^{\circ} \mathrm{C}\right]$, under : $\mathrm{FW}\left[800{ }^{\circ} \mathrm{C}\right]$ )

表 4 に見るように、 $\mathrm{P}$ 試験体では載荷速度がやや速くなっている が、最大荷重到達時までのそれらの值 (表 4 中の [ ] で示された值) に関しては、実験温度や試験体種類によらず、あまり差異が無いこ とが分かる。

\section{3. 実験結果}

高温引張試験より得られた試験体荷重〜変形関係を図 8〜11 に示 寸。これらのうち、 FW 試験体の $700{ }^{\circ} \mathrm{C}$ 加熱冷却後実験結果(図 8) に関しては、載荷初期段階で変位計治具が動いたために、常温弾性 範囲の荷重〜変形関係が正確に計測できなかった。そこで、加熱冷 却後においても鋼材の常温ヤング係数は変化しないと仮定し、そう すると FW 試験体の常温実験から得られた弾性荷重〜弾性変形関係 は $700{ }^{\circ} \mathrm{C}$ 加熱冷却後実験のそれに等しくなり、これより前者の弾 性範囲の実験結果を用いて $700{ }^{\circ} \mathrm{C}$ 加熱冷却後実験結果を修正し、 その結果を図 8 に記載した。

実験終了後の試験体観察から各試験体の破断モードを調查した。P 試験体は全て断面最小位置での破断であった。PW 試験体は基本的 に部分溶け込み溶接接合部の溶接金属破断であったが、700 ${ }^{\circ} \mathrm{C}$ 高 温実験では、テーパー区画での母材破断が見られた。ただし、後者 においても溶接金属の部分的な破断と大きな残留変形が見られた

(図 $12(\mathrm{~d})$ 参照)。FW 試験体に関しては、800 ${ }^{\circ} \mathrm{C} の$ 高温実験では完全 溶け込み溶接接合部のフュージョンライン(以下、FL) に沿って破断 しているのが確認された。それ以下の温度域 $\left(700{ }^{\circ} \mathrm{C}\right.$ 加熱冷却後実 験も含む)では、溶接接合部より断面積が大きくなるテーパー区間 での母材破断であった。図 12 に、溶接接合部を含む FW と PW 試験 体に対して、RT、700、800 ${ }^{\circ} \mathrm{C}$ の試験体破断写真を示す。また図 13、14 には、 $800{ }^{\circ} \mathrm{C} の \mathrm{FW}$ と $\mathrm{PW}$ 試験体について、試験体横方向か らの破断写真を示す。このうち図 14 の PW 試験体は、溶接金属部の 破断面 (部分溶け込み溶接部のルート面も把握できる) 写真も示して いる。図 13 より、 $800{ }^{\circ} \mathrm{C} の \mathrm{FW}$ 試験体は、FLに沿って鋼板板厚内 の溶接ビード形状が把握できるような破断面が観察されていること

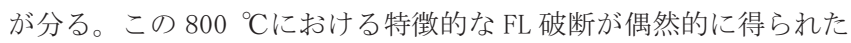
可能性もあったので、前述の通り、FW 試験体については $800{ }^{\circ} \mathrm{C} の$

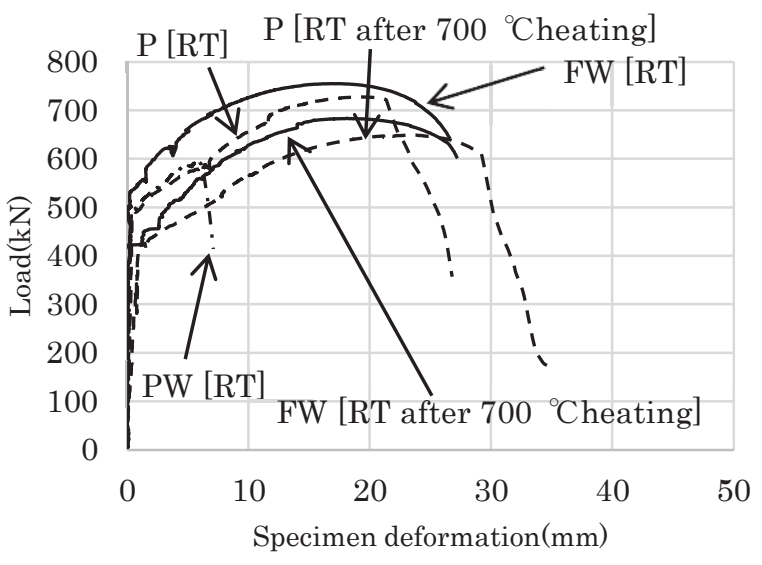

Fig.8 Load and deformation relationships [RT, RT after $700{ }^{\circ} \mathrm{Cheating]}$

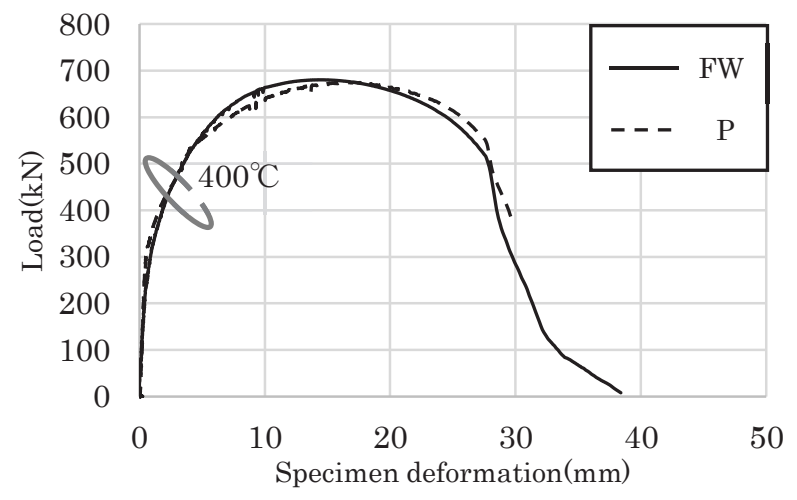

Fig.9 Load and deformation relationships $\left[400{ }^{\circ} \mathrm{C}\right]$

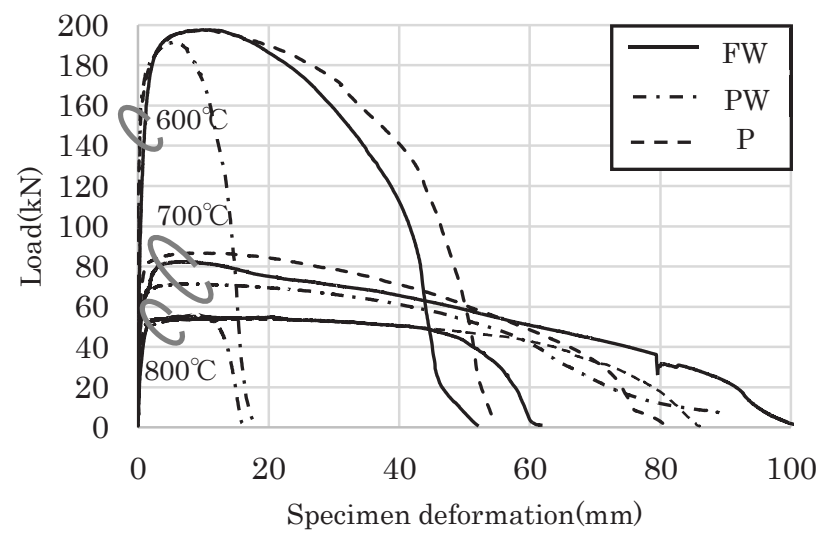

Fig.10 Load and deformation relationships $\left[600,700,800{ }^{\circ} \mathrm{C}\right]$

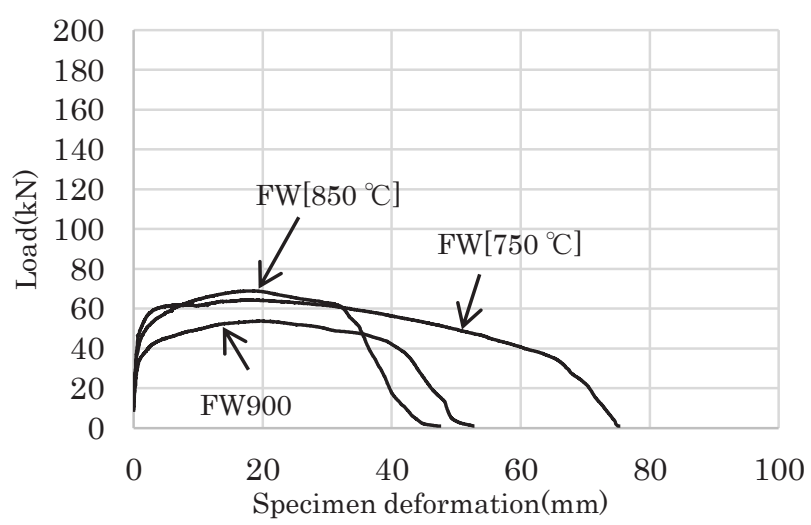

Fig.11 Load and deformation relationships $\left[750,850,900{ }^{\circ} \mathrm{C}\right]$ 
他に 750、850、900 ํㅡ 高温実験を追加実施した(図 11)。その結

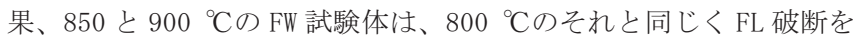
示した。一方、 $750{ }^{\circ} \mathrm{C}$ のW 試験体は、700 ${ }^{\circ} \mathrm{C}$ 以下の $\mathrm{FW}$ 試験体の破 断形状と同じく、テーパー区間内での母材破断であった。

常温実験 (図 8) に対する試験体最大荷重の大きさは、FW、P、PW 試験体の順番であった。これは、最小の PW 試験体は部分溶け込み 溶接接合部の断面積が母材の $2 / 3$ しかないため、また最大の FW 試 験体は溶接接合部に十分な強度があったために断面積が大きなテー パー区間の母材部で破断したからである。図 8～11より、温度上昇 と伴に最大荷重は低下し、一方で試験体の最大変形は増加すること が分かる。600 ${ }^{\circ} \mathrm{Cを}$ 超える温度域においては、最大荷重到達後に試 験体が直ちに破断することは無く、この場合は荷重がゼロに帰する まで試験体が変形した。700 ${ }^{\circ} \mathrm{C}$ ま゙の高温実験(図 10)では、PW 試 験体の最大荷重が最小となるが、FW と P 試験体の最大荷重には明 確な差異が見られなくなっている。 $800{ }^{\circ} \mathrm{C}$ 高温実験においては、母 材破断 ( $\mathrm{P}$ 試験体)、溶接金属破断 (PW 試験体)、FL 破断 ( FW 試験体) と試験体の破断形態はそれぞれ異なるものの、3 試験体の最大荷重 はほぼ等しくなっている(図 10)。このことについて明確な理由を 特定することはできなかったが、上記破断モードの他に、各部位の 材料特性 (鋼材、溶接金属、溶接熱影響部の高温強度) や破断位置で の断面積の違いなどの要因も考えられ、これらの要因が影響し合う ことで、結果的に 3 試験体の最大荷重がほぼ等しくなったのではな いのかと推察される。また図 11 に見るように、 $850{ }^{\circ} \mathrm{C}$ の FW 試験体 の最大荷重の方が、 750 や $800{ }^{\circ} \mathrm{C}$ のれろより、僅かな值ではあ るが大きくなった。この理由についても明確には特定できなかった が、これら試験体の最大荷重時までの平均載荷速度は、750、 800、850 ${ }^{\circ} \mathrm{C}$ でそれぞれ 0.38、0.32、0.47 mm/min(表 4、5)であっ たため、この載荷速度の差が影響を及ぼした可能性も考えられる。

試験体の変形性能に関しては、PW 試験体では断面最小部の部分 溶け込み溶接部に変形集中寸るために最大変形量は小さくなった (例えば、図 10 中の $600{ }^{\circ} \mathrm{C}$ 試験結果参照)。ただし $700{ }^{\circ} \mathrm{C} の \mathrm{PW}$ 試 験体 (図 10) に関しては最大変形量はあまり低下しておらず、これ は図 12 (d)に見るように、当該試験体は、他の PW 試験体とはやや 異なる破断形態であった、すなわち溶接金属部にも大きな塑性変形 が発生して最終的に母材破断したためと考えられる。 P と FW 試験 体に関しても、実験後の試験体観察から破断箇所近傍での変形集中 とネッキングは確認されたものの、これらは試験体のテーパー区間 内には全体的に大きな塑性変形が残留していることも確認された。 試験体内において塑性変形領域が拡大して、これが試験体の変形量 増大に寄与したものと考えられる。また図 10、11より、FL 破断し た FW 試験体 (800、850、900 $\mathrm{C}$ のそれら) についても、その最大変形 は母材破断した他の FW 試験体と比べて大幅に低下している訳では 無く、実際、試験体内には大きな塑性変形が残留していることが確 認された(図 12 (e)参照)。

$700{ }^{\circ} \mathrm{C}$ 加熱冷却後の実験結果に関しては、FW、P 試験体の最大 荷重はどちらも常温実験のそれらと比べてやや低下した。これは $700{ }^{\circ} \mathrm{C}$ の温度履歷を受けた母材部 (SN490B) の強度低下の影響が現れ たものと考えられる。700 ${ }^{\circ} \mathrm{C}$ 温度履歴を受けた FW 試験体につい ても、その破断形状は常温のそれと同じく母材破断であり、したが って加熱泠却後においても溶接接合部の最大耐力はあまり低下寸る

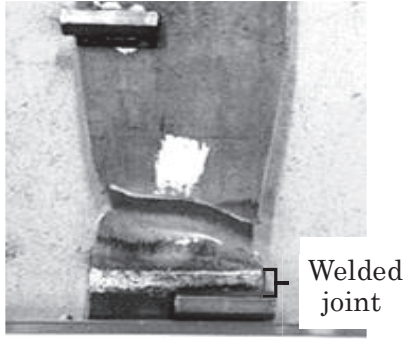

(a)FW[RT]

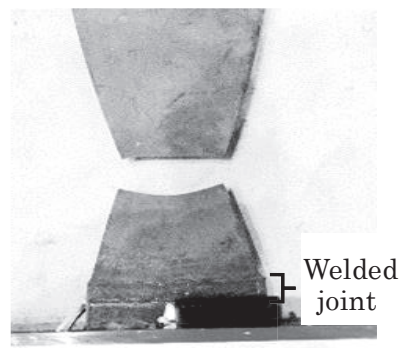

(c) $\mathrm{FW}\left[700{ }^{\circ} \mathrm{C}\right]$

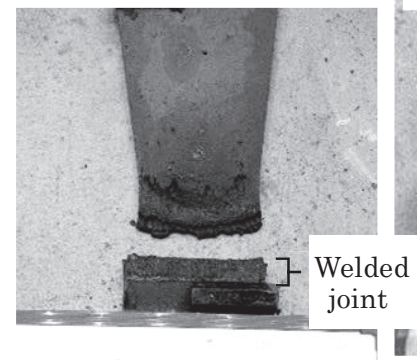

(e)FW[800 $\left.{ }^{\circ} \mathrm{C}\right]$

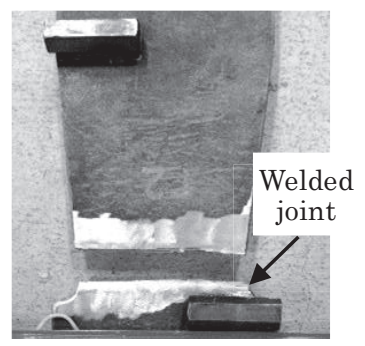

(b)PW[RT]

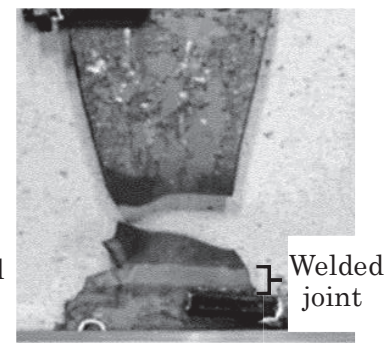

(d) $\mathrm{PW}\left[700{ }^{\circ} \mathrm{C}\right]$

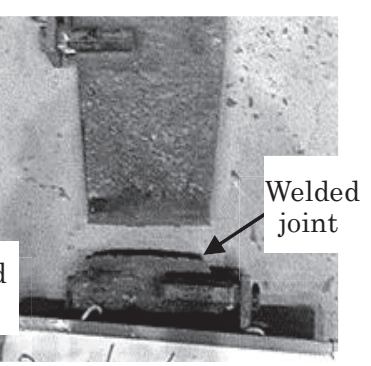

(f) $\mathrm{PW}\left[800{ }^{\circ} \mathrm{C}\right]$

Fig.12 Photographs of specimen after the tests

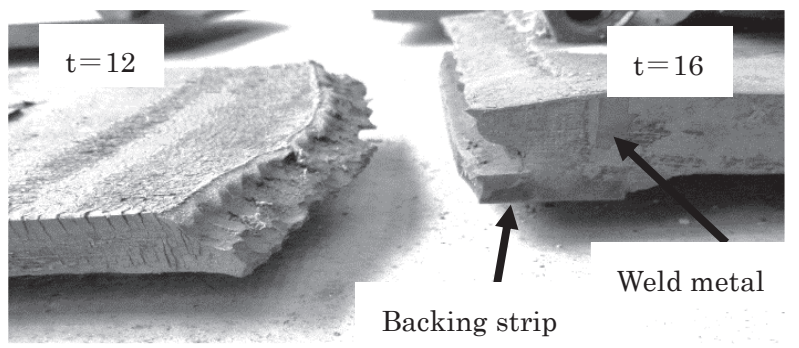

Fig.13 Photograph of the FW specimen[800 $\left.{ }^{\circ} \mathrm{C}\right]$

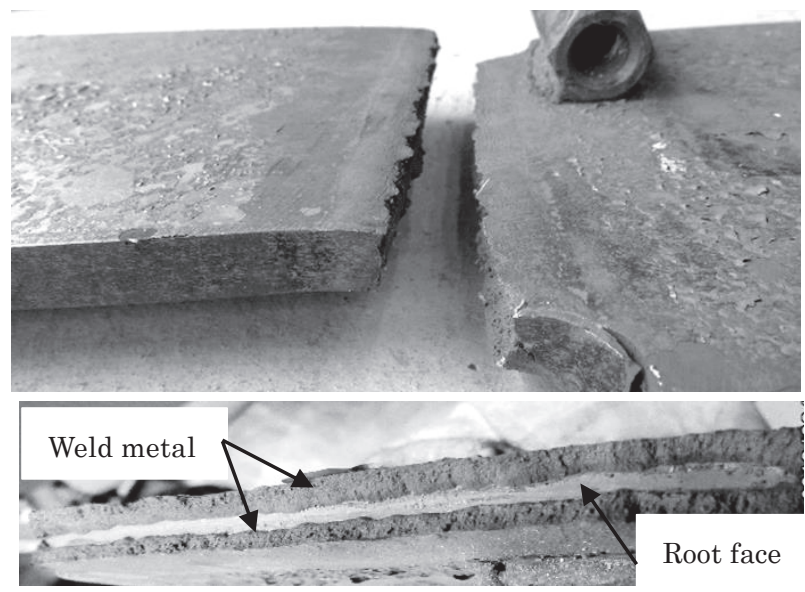

Fig.14 Photographs of the PW specimen $\left[800{ }^{\circ} \mathrm{C}\right]$ (Upper : side view ,under : fracture surface) 
ことは無かったものと考えられる。

\section{4. 溶接接合部の高温耐力・変形性能}

図 15 に、試験体最大荷重と実験温度の関係を一括にして示す。 前述の通り、常温時の FW、PW、P 試験体の最大荷重には差が見られ るものの、600 ${ }^{\circ} \mathrm{C}$ 上の温度域ではそれらはほぼ等しくなってい る。 PW と P 試験体に対しては、破断箇所における鋼材の最大応力 を算出した結果を図 16 に示す。図 16 の最大応力は、試験体最大荷 重を破断位置の断面積 ( $\mathrm{P}$ 試験体は母材最小断面積、PW 試験体は部 分溶け込み溶接接合部の断面積)で除した商である。これらは溶接 金属 (YGW-11) と母材 (SN490B)の高温引張強さに相当することとな る。なお、 $700{ }^{\circ} \mathrm{C}$ の PW 試験体はテーパー区画の母材部で最終的に 破断したが、部分溶け込み溶接接合部にも大きな破断亀裂が見られ たので、ここでは、部分溶け込み溶接接合部の断面積を用いて最大 応力を算出した。図 16 より常温時には溶接金属の引張強さの方が 大きいが、700 ${ }^{\circ} \mathrm{C}$ 以上では溶接金属と母材の引張強さはほぼ同じに なることが分かる。すなわち、高温になるにつれて溶接金属と母材 の強度差が小さくなり、このため溶接接合部での高温破断が発生し 易くなると考えられる。完全溶け込み溶接の場合においても、文献 11) や本実験結果では溶接接合部の高温破断が確認されており、特に 本実験の FW 試験体に関しては、溶接金属部に僅かな余盛が残って いたために溶接金属部では破断せず、溶接金属と母材の固着部の境 界ライン $(\mathrm{FL})$ が最弱点となって、そこが高温破断したものと推察さ れる。

図 17 には、FW、PW、P 試験体に対して、各温度の最大荷重を常 温時のそれらで除して得られた高温強度低下曲線を示す。図 17 に 見るように、600 ${ }^{\circ} \mathrm{C}$ 以上では 3 試験体の高温強度残存率は、ほぼ同 じ曲線を描くことが分かる。 $800{ }^{\circ} \mathrm{C}$ 以上の $\mathrm{FW}$ 試験体に関しては 溶接接合部の FL で破断したが、この場合の高温耐力に関しては母 材 $(\mathrm{P}$ 試験体) と同等程度有するものと考えられる。FW と $\mathrm{P}$ 試験体に 対しては、 $700{ }^{\circ} \mathrm{C}$ 加熱冷却後の実験結果も併記しており、それらは 常温の試験体と比較して、最大荷重が約 $10 \%$ 低下している。これ は前述の通り、母材部の加熱冷却による材質変化の影響が現れたか らである。

図 18 には、最大荷重到達時の試験体変形 $\Delta_{\mathrm{U}}$ と実験温度の関係 を示す。PW 試験体 (図 18 中一点鎖線) は、他の試験体と比べて変形

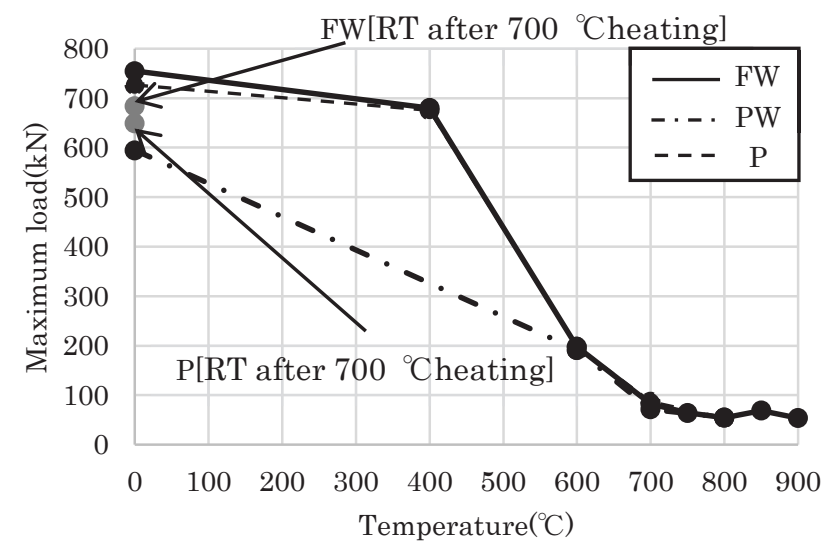

Fig.15 Maximum load and test temperature relationships

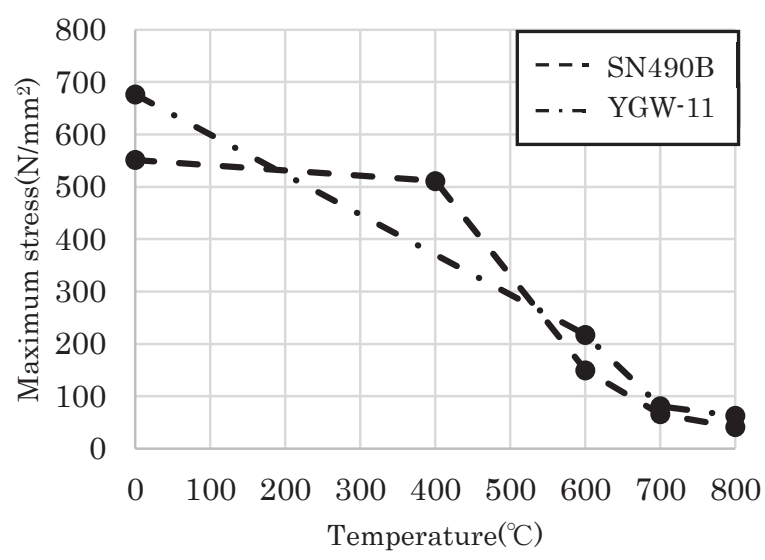

Fig.16 Maximum stress and test temperature relationships

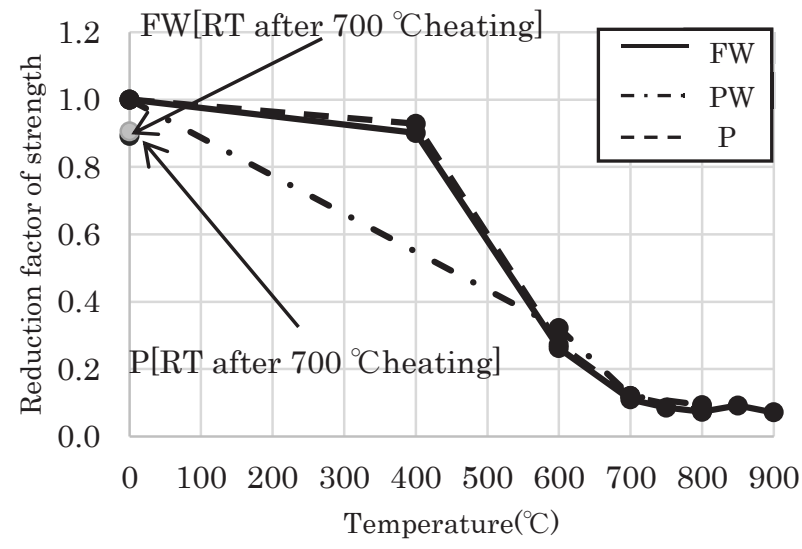

Fig.17 Reduction of strength at high temperature

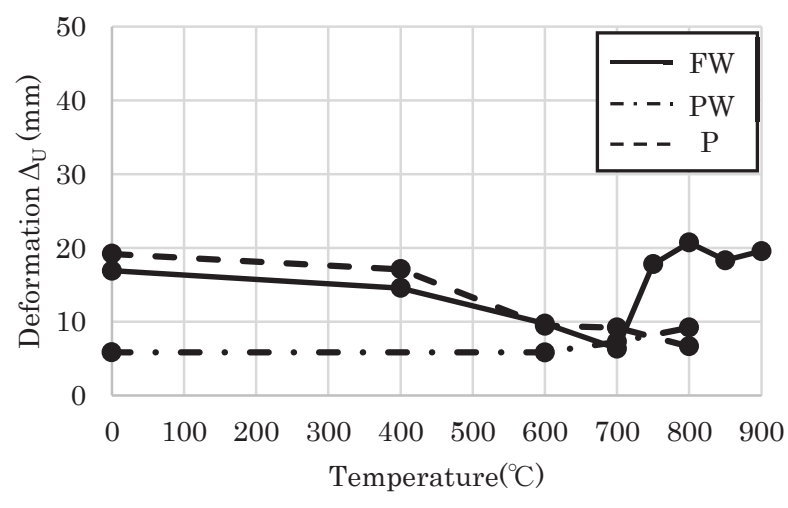

Fig.18 Deformation at the maximum load and test temperature relationships

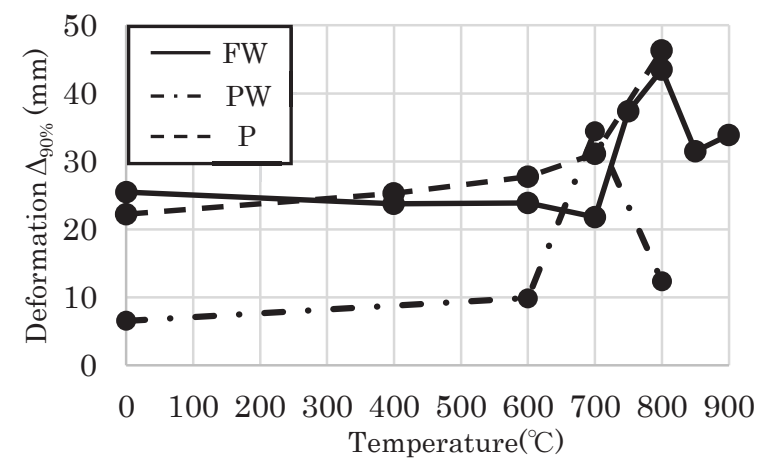

Fig.19 Deformation at the $90 \%$ maximum load and test temperature relationships 
が小さく、また温度によって最大荷重時変形 $\Delta_{U}$ はあまり変化しな いことが分かる。一方、P 試験体と $700{ }^{\circ} \mathrm{C}$ 以下の FW 試験体では高 温になるにつれて $\Delta_{U}$ が減少傾向にある。これは高温載荷中の試験 体ではネッキングや荷重のリラクゼーションが発生しやすくなるか らだと考えられる。他方で $750{ }^{\circ} \mathrm{C}$ 以上の FW 試験体の最大荷重時変 形 $\Delta_{U}$ は約 $20 \mathrm{~mm}$ に上昇している。これらは FL 破断した試験体の範 囲に概衫該当し、これら実験では FL が最弱の断面位置となるが、 余盛された溶接金属部が隣接しているために当該部のネッキングの 発生が遅れ、これが $\Delta_{U}$ の低下抑制の一要因になったことが考えら れる。

上記の最大荷重時変形 $\Delta_{\mathrm{U}}$ 到達後も高温時の試験体は荷重漸減とと もに変形が継続した。そこで図 19 に、最大耐力後の変形性能の指 標例として、最大耐力から $10 \%$ の耐力減少した時(すなわち、90\% 最大荷重時) の試験体変形 $\Delta_{90 \%}$ 温度関係を示す。本論において $90 \%$ 最大荷重時変形 $\Delta_{90 \%}$ を用いた特段の理由は無いものの、最大 荷重から $10 \%$ の耐力劣化をきたした点が溶接接合部の健全性限界 点であると仮定して、それらの変形量を評価してみた。この場合は、 図 19 見るように、P と FW 試験体の変形量は高温につれて増加傾向 にあることが分かる。一方で、 $850{ }^{\circ} \mathrm{C}$ 以上の $\mathrm{FW}$ 試験体では変形量が 小さくなっているが、これらは FL 破断であったために、最大耐力を 超えた後 (すなわち、最大荷重到達時変形 $\Delta_{U}$ を越えた後) の荷重低下 がやや急になったためと考えられる。図 19 において $700{ }^{\circ} \mathrm{C} の \mathrm{PW}$ 験体の変形量 (図 19 の一点鎖線) が増加しているが、これは前述の 通り、当該試験体だけ部分溶け込久溶接が大きく変形して破断に至 ったためである。

\section{5. まとめ}

建築構造用鋼材 (SN490B) と溶接金属 (YGW-11) を用いた完全および 部分溶け込み溶接接合部を含む鋼板試験体に対して、温度一定・荷 重漸増の高温引張試験を実施し、それらの高温耐力・変形性能を検 討した。部分溶け込み溶接接合部の場合には溶接金属部において破 断し、一部の実験 (700 ${ }^{\circ} \mathrm{C}$ 高温実験) では母材部で最終的に破断した ものも見られたが、この場合も部分溶け込み溶接接合部には大きな 亀裂と塑性変形が確認された。一方、完全溶け込み溶接接合部 の場合には、 $800{ }^{\circ} \mathrm{C}$ 以上の温度域において溶接金属部と母材熱影響 部のフュージョンライン $(\mathrm{FL})$ で破断し、それ以下の温度域について は母材 (SN490B) 破断であった。いずれの試験体に対しても延性的な 破断モードであり、FL 破断した試験体に対しても、それらの高温 耐力は母材破断したものと同等程度を有すること、さらに $\mathrm{YGW}-11$ の溶接金属部に対する高温強度残存率は、母材のそれとほぼ同等で あることを確認した。また火災後の溶接接合部の健全性評価に対寸 る実験データ収集のため、700 ${ }^{\circ} \mathrm{C}$ ま加熱した後に試験体を炉内冷 却し、その後常温引張実験を実施した。700 ${ }^{\circ} \mathrm{C}$ の加熱履歴による母 材部 (SN490B) の耐力低下は見られたが、完全溶け込み溶接接合部で 破断することは無かった。

本研究で新たに得られた溶接接合部と溶接金属の実験データは、 鋼構造而火設計における溶接接合部の耐火性能評価の基礎資料にな り得るものと考えられる。しかしながら対象鋼種と溶接材料の組合 せは限定的であり、今後も実験データ蓄積が必要と考えられる。特 に、近年では高強度鋼を用いた建築構造が多く実用化されている
が、それらの溶接接合部や溶接金属の耐火性能は不明のままであ

り、それら研究も今後必要と考えられる。

\section{謝辞}

本研究は科学研究費助成事業、若手研究 (A)「研究題目: 鋼構造に おける溶接接合部の耐火性能解明と耐火設計法構築」と日本鉄鋼連 盟研究教育助成事業から助成を受けた。記して謝意を表す。

\section{参考文献}

1）日本建築学会: 鋼構造接合部設計指針, 2012

2）日本建築センター: 鉄骨梁端溶接接合部の脆性的破断防止ガイドライ ン・同解説, 2006.6

3）日本建築学会: 鋼構造耐火設計指針, 2008

4）平島岳夫, 濱田直之, 尾崎文宣, 安部武雄, 上杉英樹: 高温時における高力 ボルトの剪断変形性状に関する実験的研究, 日本建築学会構造系論文集, 第 621 号, pp. 175-180, 2007. 11

5）平島岳夫, 江峷佑, 安藤秀平: 高温時における高力ボルト摩擦接合継手の 変形性状, 日本建築学会構造系論文集, 第 698 号, pp541-548, 2014. 4

6）尾崎文宣, 河野守: 高温時における高力ボルト接合梁継手の曲げ強度, 日 本建築学会構造系論文集, 第 589 号, pp. 187-194, 2005. 3

7）尾崎文宣, 川崎有貴: 火災時における鋼構造建築物柱梁接合部の延性亀 裂発生ひずみに関する研究一その 1 溶接接合部の火災時脆性破壊性能 評価法の提案-, 日本建築学会大会学術講演梗概集, 防火, pp. 2324, 2015.9

8) Minh-Phuong Nguyen - Kang-Hai Tai $\cdot$ Tat-Ching Fung and Thu-Mai Le(2014) : STRUCTURAL BEHAVIOUR OF WELDED FLANGE BOLTED WEB BEAMTO-COLUMN COMPOSITE JOINTS IN FIRE CONDITIONS, Proceeding of the $8^{\text {th }}$ International Conference on Structures in Fire,pp. 811$818,2014.6$

9）尾崎文宣, 菅野良一, 半谷公司: 火災時における鋼梁の塑性変形々構造而 火性能-架構内に配された鋼梁の熱応力減衰能力と素材歪硬化の関係-, 日本建築学会構造系論文集, 第 672 号, pp. 315-322, 2012.2

10）川崎有貴, 尾崎文宣: 火災時における鋼構造建築物柱梁接合部の延性亀 裂発生ひずみに関する研究一その 2 延性亀裂発生ひずみの定量化-, 日 本建築学会大会学術講演梗概集, 防火, pp. 25-26, 2015.9

11）宮坂輝由, 河野守, 岡崎智仁, 鈴木淳一, 鈴木弘之: 建築構造用鋼材溶接接 合部の高温引張試験, 日本建築学会大会学術講演梗概集, 防火, pp. 205206, 2014. 9

12）東清三郎, 二階堂真人:通しダイアフラム形式柱梁接合部の梁フランジ 溶接部の低温継手引張実験, 日本建築学会大会学術講演梗概集, 構造 III, pp. 737-738, 2014. 9

13）日本建築学会:建築工事標準仕様書 JASS6 鉄骨工事, 2015.3 


\section{TENSILE TESTS OF STEEL WELDED JOINTS AT HIGH TEMPERATURE}

\section{Yuki KAWASAKI* and Fuminobu OZAKI**}

* Grad. Stud., Grad. S. Environmental Studies, Nagoya Univ., B.Eng.

** Assoc. Prof., Grad. S. Environmental Studies, Nagoya Univ., Dr.Eng.

Verification on load-bearing performance for a steel welded joint, which is usually used for a beam-column joint in a steel rigid frame, is of importance to secure structural safety of steel building structures. Many researches using experimental, numerical and theoretical approaches on that have been conducted since the Kobe Earthquake (1995) in Japan, when many welded joints were brittlely fractured. The verification methods used at actual structural design have been established, because the seismic performance was clarified by their valuable research results. On the other hand, there are few past researches on the fire resistant performance, hence that cannot be verified at fire resistant design for the steel structures. Main purpose of this study is to clarify the load-bearing capacity of the welded joints at high temperature and accumulate the experimental date using for the fire resistant verification.

The tensile tests under a condition on constant temperature and monotonic loading were conducted. After heating specimens by an electric furnace, tensile force was gradually applied for them. The specimens including a full penetration (FW specimen) or partial penetration (PW specimen) welded joint were fabricated. The base metal and weld material are JIS SN490B and JIS YGW11, respectively. For comparison of the experimental data of the welded specimens, the specimen without the welded joint (P specimen) was used for the experiments. All specimens were fabricated into a tapered shape. The welded joint was arranged at the minimum sectional area of the tapered shape specimen. The test temperatures from ambient temperature to $800{ }^{\circ} \mathrm{C}$ were used. For the $\mathrm{FW}$ specimen, the tensile tests were additionally conducted up to $900{ }^{\circ} \mathrm{C}$. From a series of the tensile tests at the high temperature, the following experimental results were obtained.

The maximum load of the specimen gradually decreased with the test temperature increase. At the ambient temperature, the specimens ductility fractured after the peak of tensile load. On the other hand, they did not fracture after the peak at the high temperature and exhibited residual strength. In this region, the tensile load gradually decreased with the deformation increase. The PW specimens fractured at the weld metal in the partial penetrate welded joints. The FW specimens over $800{ }^{\circ} \mathrm{C}$ fractured along fusion lines between the weld metal and the heat affected zone, otherwise they fractured at the base metal. However, the specimens fractured at the welded joints possessed the sufficient load bearing and deformation capacity at the high temperature. From specimen observations after the tests, large residual plastic deformations in the tapered shape specimen and necking at the fractured section were observed for all specimens. The reduction factor on the tensile strength of the specimen including the welded joint, which is fundamental information to verify the fire resistant performance of welded joint, was estimated by the obtained experimental results. From the reduction factor curves at the elevated temperature, it was confirmed that both welded joint and base metal possessed the similar reduction factors over $600{ }^{\circ} \mathrm{C}$. 